\title{
Antihypertensive Treatment and Renal Protection: the role of drugs inhibiting the renin-angiotensin-aldosterone system
}

\author{
Francesca Viazzi • Giovanna Leoncini • \\ Roberto Pontremoli
}

Received: 19 September 2013/Accepted: 26 September 2013/Published online: 4 October 2013

(C) The Author(s) 2013. This article is published with open access at Springerlink.com

\begin{abstract}
The prevalence of chronic kidney disease, currently estimated to vary between 8 and $12 \%$ in the general population, is steadily rising due to aging and to the ongoing epidemic of hypertension and type 2 diabetes. Even in its early stages, chronic kidney disease entails a greater risk for cardiovascular mortality, and its prevention and treatment is rapidly becoming a key medical issue for many health care systems worldwide. Adequate blood pressure control and reduction of urine protein excretion, preferably obtained by the use of renin-angiotensin-aldosterone system inhibitors, have traditionally been considered the mainstay of therapeutic strategies in patients with renal disease. Given the pivotal role of renin-angiotensin-aldosterone system activity in the pathogenesis and progression of renal and cardiovascular damage, a more profound inhibition of the system, either by the use of multiple agents or by a single agent at high dosage has recently been advocated, especially in the presence of proteinuria. Recent trials, however have failed to confirm the usefulness of this therapeutic approach, at least in unselected patients. This article will critically review the current literature and will discuss the clinical implications of targeting the reninangiotensin-aldosterone system in order to provide the greatest renal protection.
\end{abstract}

Keywords Chronic kidney disease - Hypertension · Renin-angiotensin-aldosterone inhibitors · Proteinuria

F. Viazzi · G. Leoncini · R. Pontremoli $(\bowtie)$ Università degli Studi e I.R.C.C.S. Azienda Ospedaliera Universitaria San Martino-IST, Istituto Nazionale per la Ricerca sul Cancro, Viale Benedetto XV, 16125 Genoa, Italy

e-mail: roberto.pontremoli@unige.it

\section{Introduction}

Chronic kidney disease (CKD) is currently estimated to affect between 8 and $12 \%$ of the general population, and its prevalence may be as high as $20-30 \%$ in subgroups at increased risk such as patients with diabetes, hypertension and the elderly [1-3]. The economic impact of renal diseases is steadily growing worldwide and its prevention and treatment is becoming a priority for many public health systems. In its early stages, besides the obvious risk of progressing to end stage renal disease (ESRD) and the need for renal replacement therapy, renal damage represents a formidable multiplier of global cardiovascular (CV) risk [4-6]. In fact, the presence of increased albuminuria or a mild reduction in glomerular filtration rate, albeit typically asymptomatic and often overlooked, entails a manifold higher risk of unfavorable $\mathrm{CV}$ events [7]. CKD, especially in the presence of significant proteinuria, typically remains a progressive condition and since the decline in renal function is paralleled by further increase in the burden of risk, many patients actually die from $\mathrm{CV}$ complications well before reaching ESRD [8, 9]. Although optimal treatment for CKD has not yet been established, current therapeutic strategies aim at correcting and optimizing traditional and kidney specific CV risk factors. In this respect, high blood pressure may well be regarded as a special condition since it is known to be both a cause and a consequence of renal damage [10]. Effective antihypertensive treatment has clearly been shown to attenuate the worsening of renal function and to reduce proteinuria [11]. While optimal blood pressure levels are still a matter of debate and may vary on the basis of clinical conditions such as the presence of diabetes and/or the degree of proteinuria, there is consensus that maximizing the reduction of urinary protein excretion is associated with better renal 
outcome, regardless of blood pressure changes and may represent an intermediate target of treatment. International guidelines unanimously recommend the use of reninangiotensin-aldosterone system (RAAS) inhibitors as the pharmacological agent of choice to treat hypertension and provide renal protection in CKD patients [12, 13]. The well established pathogenetic role of the RAAS in promoting and sustaining renal damage, both at experimental and clinical levels, has led researchers to test the hypothesis that a more profound inhibition of the system, achieved through the concomitant use of multiple agents or through the supramaximal dosage of a single agent may confer additional therapeutic benefits. Recent clinical trials however do not seem to confirm this somewhat oversimplified therapeutic scenario and once more emphasize the need for a careful and individualized approach to antihypertensive treatment in the renal patient $[14,15]$. This article will briefly review the recent literature on the pros and cons of the use of RAAS-inhibitors and provide a practical algorithm to optimize antihypertensive treatment in patients with CKD.

\section{Blood Pressure Lowering Reduces Proteinuria and Conveys Renal and CV Protection}

The magnitude of systolic blood pressure reduction as well as the degree of proteinuria reduction has been related to renal outcome in patients with non diabetic CKD, with greater renal protection being obtained when these two variables are lowered to a range of $110-130 \mathrm{mmHg}$ and below $1.5 \mathrm{~g} /$ day, respectively [16-18]. Furthermore, results of the RENAAL and IDNT trials [19] indicate that residual blood pressure and urine protein excretion levels, i.e. those that can be achieved under optimal antihypertensive treatment, are far more important for long term renal protection as compared to baseline values. Specifically, the prognostic power of residual proteinuria seems to outweigh that of blood pressure since a graded relationship between the degree of proteinuria and the risk of reaching ESRD was observed for each systolic blood pressure strata [20]. Furthermore, better long-term renal survival in patients with overt proteinuria assigned to more intensive blood pressure reduction was confirmed by recently published data from the AASK study [21]. A similar relationship between albuminuria and renal outcome has been shown to apply also to earlier stages of the disease as indicated by an association of albuminuria reduction with better preservation of GFR in the STENO-2 study carried out on patients with type 2 diabetes [22]. Based on these data, international guidelines have rather unanimously recommended blood pressure values $<130 / 80 \mathrm{mmHg}$ (with some indicating even lower values, i.e. $<125 / 75 \mathrm{mmHg}$ when proteinuria exceeds $1 \mathrm{~g} / \mathrm{die}$ ) [23]. Recently, however, the wisdom and evidence in favor of such a strict, often difficult to achieve blood pressure target has been disputed since the untoward, paradoxical increase in mortality (so called J curve phenomenon) observed with progressively lower blood pressure regimens has been confirmed in several trials, especially in diabetics and coronary artery disease subgroups. Thus, it appears that while preservation of kidney function may well be better obtained by maximal blood pressure reduction, especially in the presence of proteinuria, an overly ambitious target may not always be recommended in the overall interest of at least some CKD patients, as global risk profile and the need to optimize cerebrovascular and cardiac protection must be taken into account as well [24].

\section{RAAS Inhibitors: Renal Protection Beyond Blood Pressure Reduction?}

Extensive experimental and clinical evidence, accrued over more than three decades, document the deleterious effects of increased RAAS activity at the vascular and tissue level, especially within the kidney [25]. An excess of angiotensin II increases intraglomerular pressure by preferentially constricting the efferent arterioles, thus promoting glomerular hypertension and protein trafficking through the glomerular basal membrane [26, 27]. Furthermore, angiotensin II stimulates aldosterone production and triggers the activation of a cascade of profibrotic cytokines whose activation ultimately leads to cellular glomerular sclerosis and tubule-interstitial fibrosis [28, 29]. Given these pathophysiological premises it is certainly not surprising that antihypertensive agents which specifically inhibit RAAS activity at various levels may exert antiproteinuric and renoprotective effects even beyond their systemic hemodynamic effect on blood pressure. Clinical confirmation of this hypothesis was first provided in the early nineties by the Collaborative Study Group Trial, whose results documented how the ACE-Inhibitor captopril afforded greater proteinuria reduction and better renal survival as compared to placebo in type 1 diabetic patients with overt renal disease. Blood pressure reduction however was slightly but significantly lower in the captopril arm, making it harder to quantify precisely how much of the observed renal protection was specifically attributable to the drug's mechanism of action [30]. Greater renal protection as compared to placebo was later reported with other ACE-Inhibitors (ACE-I), namely ramipril and benazepril, in the REIN study [31] and in the AIPRI study [32], both conducted on non diabetic patients with proteinuric kidney diseases.

At the beginning of this century, the then new class of angiotensin II type I receptor blockers (ARBs) was tested 
(again vs placebo) on the subgroup of patients that were rapidly becoming the most prevalent in renal practice everywhere, i.e. those with type 2 diabetes. In two similar landmark trials [33, 34], losartan and irbesartan, given on top of standard antihypertensive therapy, proved superior to placebo in reducing proteinuria and the rate of renal function loss over time, despite similar blood pressure reduction. Although only a few clinical trials have formally tested a head to head comparison between ACE-Is and ARBs, based on the results of several small studies and one reasonably large trial (comparing telmisartan and enalapril in patients with type 2 diabetes and incipient renal disease) [35], ACE-Is and ARBs have traditionally been assumed to provide comparable renal protection, in the context of undisputed superior tolerability of the latter. More recently, a large trial [14], albeit not specifically carried out on renal patients, reported similar renal protection with ramipril and telmisartan in high risk patients. Despite minimal blood pressure differences between treatment arms, which required statistical adjustment, several [17, 18] but not all meta-analyses [36] have sided with the notion of a certain degree of additional, blood pressure independent renal protective effect with ACE-I or ARBs. Guidelines have so far acknowledged these results indicating $\mathrm{ARBs}$ as the preferred choice in type $2 \mathrm{DM}$ patients, and ACE-I for non diabetic renal patients.

\section{Optimizing RAAS Inhibition in Clinical Practice: The Need for Limitation}

After the initial enthusiasm over the results of trials conducted with ACE-Is and ARBs, investigators realized that in the presence of proteinuria, a disappointingly large fraction of CKD patients, with or without diabetes, tend to progress toward ESRD over a few years, despite optimal antihypertensive treatment and RAAS-inhibition. In the meantime, new experimental data uncovered several biochemical mechanisms, such as non ACE-dependent Angiotensin II formation pathways [37] or counter-regulatory supramaximal Angiotensin II production in the presence of ATI1 type I receptor blockade [38, 39], the so called aldosterone escape phenomenon, which provided the basis for hypothesizing an incomplete blockade of the RAAS both under ACE-I or ARB treatment. This led investigators to search for and test new pharmacologic strategies to obtain more profound and complete inhibition of the RAAS in order to achieve greater renal protection (Table 1).

\subsection{Dual RAAS Inhibition}

Preliminary results of several small studies and three metaanalyses [40-42] suggest that greater reduction of proteinuria could be obtained by combining treatment with an ACE-I and an ARB. One small study conducted on patients with type 1 diabetes, with a triple cross over design in 20 diabetic patients with overt proteinuria demonstrated that high dose losartan or its association with lisinopril (both at recommended doses) were superior to recommended doses of losartan in reducing proteinuria [43]. These data contributed to raising expectations that dual RAAS blockade could translate into long term reduction of hard renal endpoints. However, following formal retraction of the COOPERATE study [44, 45] and subsequently, after publication of the much awaited renal data from ONTARGET [46], it appeared that the risk/benefit ratio of RAAS combination therapy needed to be carefully reconsidered. While it has been pointed out that the ONTARGET study included only a relatively small number of CKD patients for its results to be applicable to the population of renal patients at large, especially those with overt proteinuria, this trial clearly showed that little o no $\mathrm{CV}$ benefit can be gained by combining ramipril and telmisartan in high risk patients. On the other hand, data show there is a price to pay with this therapeutic combination in terms of untoward effects, mainly hyperkalemia, hypotension and acute worsening of renal function, especially in the subgroup with impaired renal function.

The development of aliskiren [47] the first direct renin inhibitor (DRI), acting upstream of the enzymatic cascade and providing more profound inhibition as well as greater blood pressure lowering as compared to other agents, allowed to test the usefulness of higher degrees of RAAS suppression in the clinical setting. The AVOID study [48], conducted on 600 hypertensive patients with type 2 diabetes and overt renal disease, showed additional antiproteinuric action and stable renal function when aliskiren was given on top of losartan over a 6-month period, despite non significant changes in blood pressure.

More recently, however the strategy of combining aliskiren with an ACE-I or an ARB in diabetic patients at high cardiorenal risk was shown to entail potentially unfavorable effects. The ALTITUDE study, which was conducted on 8,500 patients, had to be prematurely stopped due to what turned out to be a lack of benefit, possibly associated with a greater risk of complications [15]. Thus, it appears that the risk-benefit ratio of pharmacological inhibition of the RAAS may vary along the renal continuum and seemingly paradoxical effects may be had when inhibition becomes too profound or the clinical setting becomes critical. While it is unlikely that dual RAAS inhibition does any good to cardiovascular health, further studies are certainly needed before it can be concluded that it is detrimental to CKD patients, and some ongoing trials may provide the much needed information. The VA NEPHRON-D trial will investigate the effect of combining 


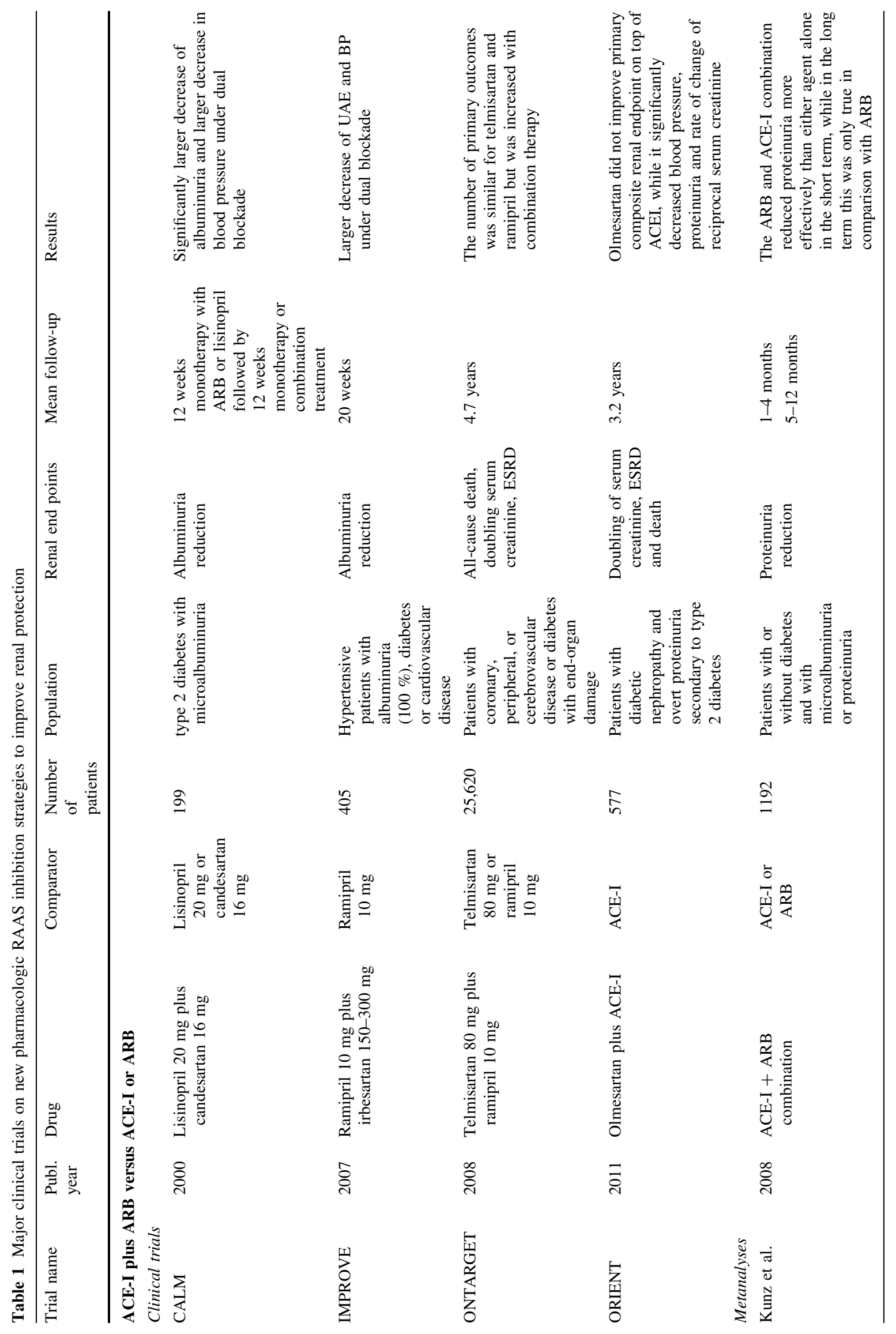




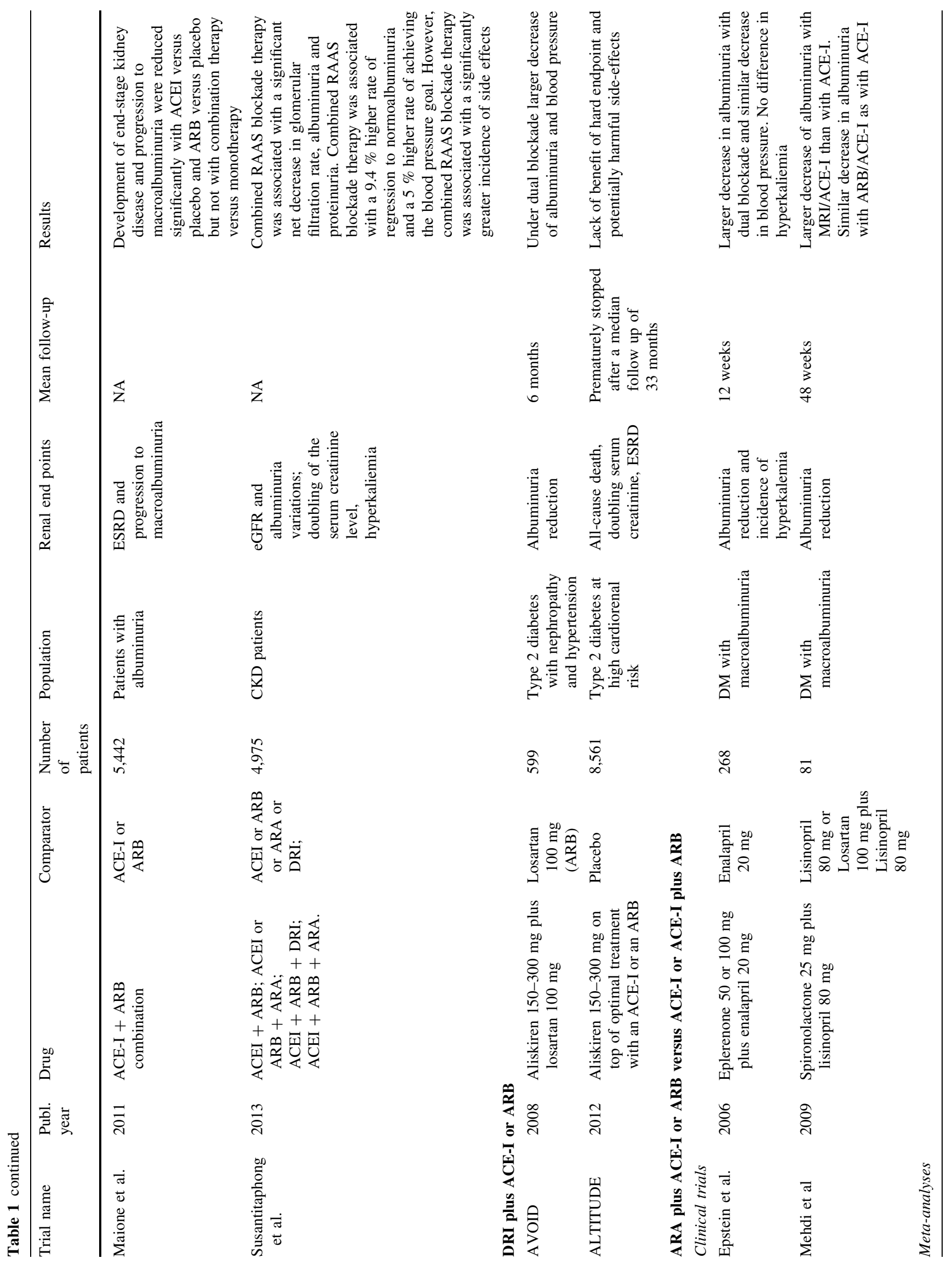




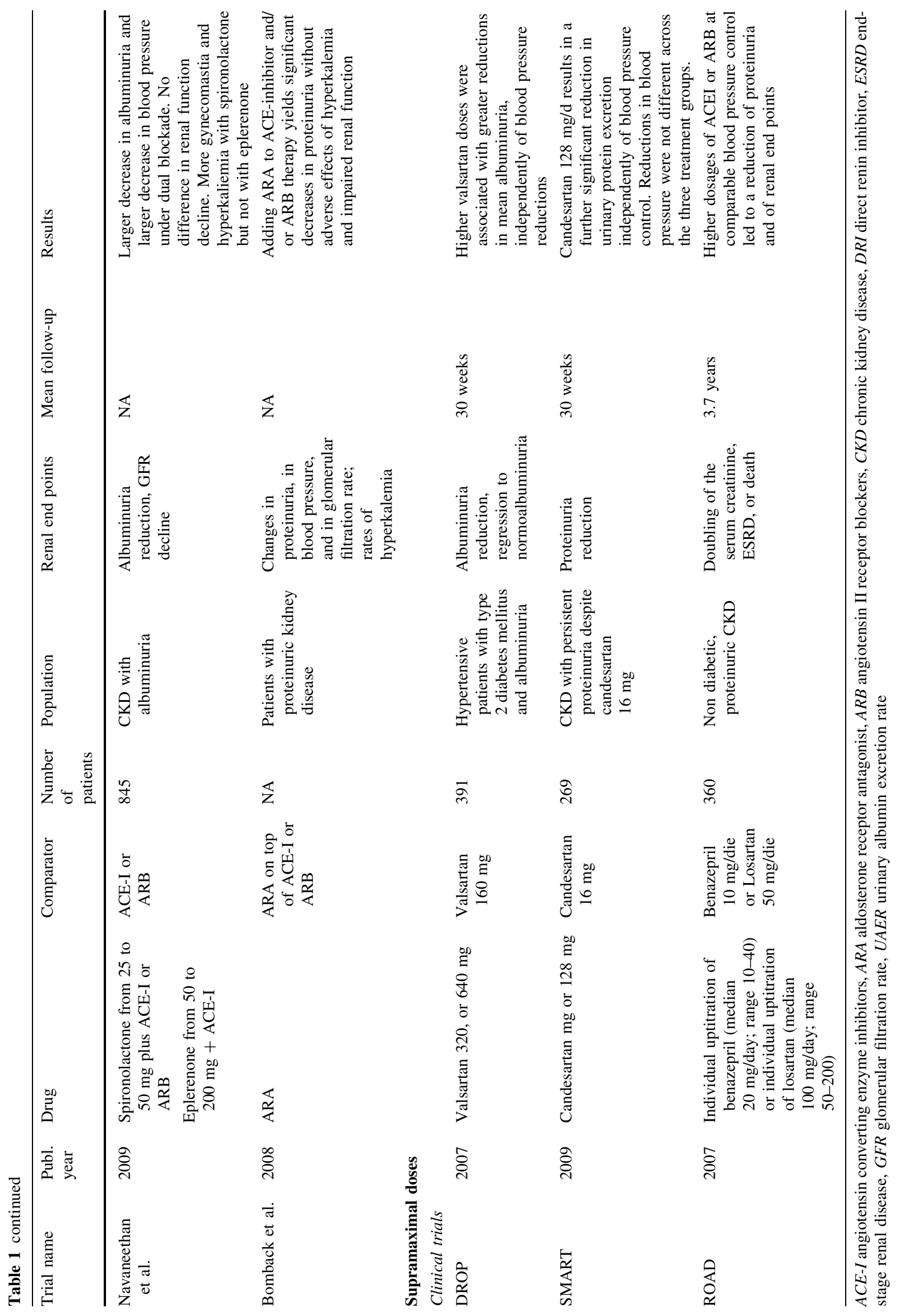


losartan and lisinopril as compared to losartan alone in patients with diabetes and overt proteinuria [49]. Furthermore, the LIRICO [50] and VALID [51] studies will again evaluate dual therapy with either an ACE-I or an ARB in patients with micro-macroalbuminuria and in those with type 2 diabetes and overt nephropathy, respectively.

\subsection{Single Agent High Dose RAAS Inhibition}

Based on experimental studies indicating different degrees of RAAS activity and drug effectiveness at the circulating and tissue level [52-54], with the latter possibly more accurately reflecting the development of organ damage in the long term, it has been proposed that supra pharmacological doses of RAAS-inhibiting drugs might provide greater renal benefit. Indeed, a few short-term studies have documented dose-dependent reductions of proteinuria, even regardless of hemodynamic changes [55-58]. Two studies have investigated this possibility under chronic conditions over the medium-long term. In the DROP study [57], treatment of patients with type 2 diabetes and albuminuria with increasingly high doses of valsartan (up to $640 \mathrm{mg} /$ day) were associated with a significantly greater reduction in proteinuria and marginally lower blood pressure. Along the same lines, in the SMART study [58], 269 non diabetic CKD patients with clinical proteinuria were treated with candesartan up to $128 \mathrm{mg}$ /day. While supramaximal doses did not seem to affect blood pressure values, urinary loss of protein was markedly reduced in a dose dependent fashion. Finally, in the ROAD study [59] uptitration of a single agent (benazepril or losartan) was compared to standard dose in 360 non diabetic patients with overt proteinuria over a three year follow-up period. Again, high dose treatment with each agent was associated with a greater antiproteinuric effect as compared to standard dose despite similar blood pressure reduction. Undoubtedly, high dose monotherapy with ACE-I or ARB appears to be a promising way to increase renal protection in CKD patients and one which certainly warrants a more in-depth evaluation by means of large well designed studies in the future.

\subsection{Aldosterone Receptor Antagonists}

Several relatively small and short term studies have shown that both spironolactone and eplerenone can produce further reductions in albuminuria/proteinuria when added to optimal treatment with an ACE-I or an ARB [60]. These favorable results are corroborated by the results of at least two meta-analyses [61, 62]. However, no long term effect on renal function or survival has been documented, while treatment is associated with a greater risk of potentially dangerous untoward effects such as hyperkalemia, particularly when eGFR is below $30 \mathrm{ml} / \mathrm{min}$. In one study, the addition of spironolactone $25 \mathrm{mg}$ on top of high dose lisinopril (i.e., $80 \mathrm{mg}$ ) was associated with further proteinuria reduction regardless of blood pressure changes [63]. Thus, notwithstanding encouraging preliminary evidence, the routine use of an aldosterone receptor antagonist (ARA) in association with an ACE or an ARB appears to be premature and warrants further study.

\section{What Role Could There Be for RAAS Inhibition in the Prevention of Renal Damage?}

The high $\mathrm{CV}$ and renal residual risk observed in patients with overt CKD despite multifactorial intensive treatment has prompted many to advocate prevention of renal damage in the subgroups of patients at risk as a way to more effectively fight the current epidemic of ESRD and associated CV diseases. Again, even in the field of primary prevention it has sometimes been difficult to distinguish the effect of blood pressure lowering from that of RAAS inhibition per se.

The BENEDICT study, carried out on patients with type 2 diabetes and hypertension, investigated the effectiveness of the ACE-inhibitor trandolapril as compared to the nondihydropyridine calcium channel blocker verapamil given alone or in combination, over a mean 3.6 year follow-up period [64]. Treatment with trandolapril was associated with a significantly lower incidence of microalbuminuria, regardless of blood pressure values [65]. In the ADVANCE trial, the combination of perindopril-indapamide proved superior to placebo in preventing or delaying the onset of microalbuminuria, although lower blood pressure values were achieved in the active treatment arm [66]. Moreover, in the DIRECT study, a large trial carried out on mostly normotensive patients with type 1 and 2 diabetes, Candesartan did not produce any valuable effect in preventing the onset of albuminuria [67]. In another study, carried out on a smaller number of patients with type 1 diabetes, neither enalapril nor losartan showed any difference as compared to placebo in preventing microalbuminuria over a 5 year follow-up [68].

Finally, in the ROADMAP study, treatment with olmesartan was more effective than placebo in delaying the onset of microalbuminuria in a large cohort of type 2 diabetics, but again in the context of a slightly greater blood pressure lowering effect as compared to placebo [69].

Taken together, these data suggest a mildly favorable role for RAAS inhibitors in the prevention of renal damage in patients with diabetes, especially in the context of hypertension. This renal protective effect however, seems at least in part due to the blood pressure lowering effect of these agents. 


\section{Conclusions}

Achieving optimal blood pressure values through effective pharmacological treatment is associated with a reduction in proteinuria and a slower rate of renal deterioration over time in patients with CKD. RAAS-Is represent the antihypertensive drugs of choice and have been shown to provide greater antiproteinuric effects at comparable blood pressure regimens. Although only a few trials have directly compared ACE-Is to ARBs, these two classes of antihypertensives appear to have similar renal protective effectiveness. The latter however, are characterized by undisputed greater tolerability. Dual RAAS inhibition with an ACE-I/ARB combination does not provide additional $\mathrm{CV}$ benefits and might have serious side effects in the renal patient. Whether these risks are worth taking in selected cases, and if the slightly greater proteinuria reduction reported with this combination will actually translate into long term benefits on hard renal end point remains to be seen. There are currently insufficient data to recommend other RAAS combinations (with ARA or DRI) and high dose monotherapy with ACE-I or ARB in order to achieve greater renal protection. This is certainly an area that warrants further clinical investigation.

In the presence of CKD, achieving blood pressure targets almost invariably requires the association of several drugs [70], not rarely three or more. The type and dose or combination of diuretic(s) is often a key factor for therapeutic success [71]. Whenever a two-drug combination is sufficient to reach the desired blood pressure target, and in the absence of other compelling indication to the use of specific drug classes, RAAS-I and CCB can successfully be used as initial treatment [72]. Finally, clinicians should always be mindful that CKD requires all antihypertensive regimens to be tailored to each specific clinical situation and within the greater context of a multifactorial strategy which must include a healthy lifestyle and dietary habits. In particular, a decrease in sodium and phosphorus intake, and a combination of antiplatelet, lipid lowering drugs and optimal gluco-metabolic control as needed.

\section{Conflicts of interest None.}

Open Access This article is distributed under the terms of the Creative Commons Attribution License which permits any use, distribution, and reproduction in any medium, provided the original author(s) and the source are credited.

\section{References}

1. Zhang QL, Rothenbacher D. Prevalence of chronic kidney disease in population-based studies: systematic review. BMC Public Health. 2008;8:117.
2. Coresh J, Selvin E, Stevens LA, Manzi J, Kusek JW, Eggers P, Van Lente F, Levey AS. Prevalence of chronic kidney disease in the United States. JAMA. 2007;298:2038-47.

3. Shastri S, Tighiouart H, Katz R, Rifkin DE, Fried LF, Shlipak MG, Newman AB, Sarnak MJ. Chronic kidney disease in octogenarians. Clin J Am Soc Nephrol. 2011;6:1410-7.

4. Chronic Kidney Disease Prognosis Consortium, Matsushita K, van der Velde M, Astor BC, Woodward M, Levey AS, de Jong PE, Coresh J, Gansevoort RT. Association of estimated glomerular filtration rate and albuminuria with all-cause and cardiovascular mortality in general population cohorts: a collaborative meta-analysis. Lancet. 2010;375:2073-81.

5. Go AS, Chertow GM, Fan D, McCulloch CE, Hsu CY. Chronic kidney disease and the risks of death, cardiovascular events, and hospitalization. N Engl J Med. 2004;351:1296-305.

6. Iseki K, Kinjo K, Iseki C, Takishita S. Relationship between predicted creatinine clearance and proteinuria and the risk of developing ESRD in Okinawa, Japan. Am J Kidney Dis. 2004;44:806-14.

7. Brantsma AH, Bakker SJ, Hillege HL, de Zeeuw D, de Jong PE, de Gansevoort RT, PREVEND Study Group. Cardiovascular and renal outcome in subjects with K/DOQI stage 1-3 chronic kidney disease: the importance of urinary albumin excretion. Nephrol Dial Transplant. 2008;23:3851-8.

8. Keith DS, Nichols GA, Gullion CM, Brown JB, Smith DH. Longitudinal follow-up and outcomes among a population with chronic kidney disease in a large managed care organization. Arch Intern Med. 2004;164:659-63.

9. Leoncini G, Viazzi F, Pontremoli R. Overall health assessment: a renal perspective. Lancet. 2010;375:2053-4.

10. Barri YM. Hypertension and kidney disease: a deadly connection. Curr Hypertens Rep. 2008;10:39-45.

11. Parving HH, Smidt UM, Hommel E, Mathiesen ER, Rossing P, Nielsen F, Gall MA. Effective antihypertensive treatment postpones renal insufficiency in diabetic nephropathy. Am J Kidney Dis. 1993;22:188-95.

12. National Kidney Foundation. K/DOQI clinical practice guidelines for chronic kidney disease: evaluation, classification, and stratification. Am J Kidney Dis. 2002;39:S1-266.

13. Mancia G, Fagard R, Narkiewicz K, Redón J, Zanchetti A, Böhm M, Christiaens T, Cifkova R, De Backer G, Dominiczak A, Galderisi M, Grobbee DE, Jaarsma T, Kirchhof P, Kjeldsen SE, Laurent S, Manolis AJ, Nilsson PM, Ruilope LM, Schmieder RE, Sirnes PA, Sleight P, Viigimaa M, Waeber B, Zannad F. 2013 ESH/ESC Guidelines for the management of arterial hypertension: the task force for the management of arterial hypertension of the European Society of Hypertension (ESH) and of the European Society of Cardiology (ESC). J Hypertens. 2013;31(7): 1281-357.

14. ONTARGET Investigators, Yusuf S, Teo KK, Pogue J, Dyal L, Copland I, Schumacher H, Dagenais G, Sleight P, Anderson C. Telmisartan, ramipril, or both in patients at high risk for vascular events. N Engl J Med. 2008;358:1547-59.

15. Parving HH, Brenner BM, McMurray JJ, de Zeeuw D, Haffner SM, Solomon SD, Chaturvedi N, Persson F, Desai AS, Nicolaides M, Richard A, Xiang Z, Brunel P, Pfeffer MA, ALTITUDE Investigators. Cardiorenal end points in a trial of aliskiren for type 2 diabetes. N Engl J Med. 2012;367:2204-13.

16. Peterson JC, Adler S, Burkart JM, Greene T, Hebert LA, Hunsicker LG, King AJ, Klahr S, Massry SG, Seifter JL. Blood pressure control, proteinuria, and the progression of renal disease. The Modification of Diet in Renal Disease Study. Ann Intern Med. 1995;123:754-62.

17. Jafar TH, Stark PC, Schmid CH, Landa M, Maschio G, de Jong PE, de Zeeuw D, Shahinfar S, Toto R, Levey AS, AIPRD Study Group. Progression of chronic kidney disease: the role of blood 
pressure control, proteinuria, and angiotensin-converting enzyme inhibition: a patient-level meta-analysis. Ann Intern Med. 2003;139:244-52.

18. Jafar TH, Schmid CH, Landa M, Giatras I, Toto R, Remuzzi G, Maschio G, Brenner BM, Kamper A, Zucchelli P, Becker G, Himmelmann A, Bannister K, Landais P, Shahinfar S, de Jong $\mathrm{PE}$, de Zeeuw D, Lau J, Levey AS. Angiotensin-converting enzyme inhibitors and progression of nondiabetic renal disease. A meta-analysis of patient-level data. Ann Intern Med. 2001;135:73-87.

19. Atkins RC, Briganti EM, Lewis JB, et al. Proteinuria reduction and progression to renal failure in patients with type 2 diabetes mellitus and overt nephropathy. Am J Kidney Dis. 2005;45:281-7.

20. Eijkelkamp WB, Zhang Z, Remuzzi G, Parving HH, Cooper ME, Keane WF, Shahinfar S, Gleim GW, Weir MR, Brenner BM, de Zeeuw D. Albuminuria is a target for renoprotective therapy independent from blood pressure in patients with type 2 diabetic nephropathy: post-hoc analysis from the Reduction of Endpoints in NIDDM with the Angiotensin II Antagonist Losartan (RENAAL) trial. J Am Soc Nephrol. 2007;18:1540-6.

21. Appel LJ, Wright JT Jr, Greene T, Agodoa LY, Astor BC, Bakris GL, Cleveland WH, Charleston J, Contreras G, Faulkner ML, Gabbai FB, Gassman JJ, Hebert LA, Jamerson KA, Kopple JD, Kusek JW, Lash JP, Lea JP, Lewis JB, Lipkowitz, Massry SG, Miller ER, Norris K, Phillips RA, Pogue VA, Randall OS, Rostand SG, Smogorzewski MJ, Toto RD, Wang X, AASK Collaborative Research Group. Intensive blood-pressure control in hypertensive chronic kidney disease. N Engl J Med. 2010;363:918-29.

22. Gaede P, Tarnow L, Vedel P, Parving HH, Pedersen O. Remission to normoalbuminuria during multifactorial treatment preserves kidney function in patients with type 2 diabetes and microalbuminuria. Nephrol Dial Transplant. 2004;19:2784-8.

23. Kidney Disease Outcomes Quality Initiative (K/DOQI). K/DOQI clinical practice guidelines on hypertension and antihypertensive agents in chronic kidney disease. Am J Kidney Dis. 2004, 43(Suppl 1):1-290.

24. Mancia G, Schumacher H, Redon J, et al. Blood pressure targets recommended by guidelines and incidence of cardiovascular and renal events in the Ongoing Telmisartan Alone and in Combination with Ramipril Global Endpoint Trial (ONTARGET). Circulation. 2011;124:1727-36.

25. Siragy HM, Carey RM. Role of the intrarenal renin-angiotensinaldosterone system in chronic kidney disease. Am J Nephrol. 2010;31:541-50.

26. Ruiz-Ortega M, Lorenzo O, Suzuki Y, Ruperez M, Egido J. Proinflammatory actions of angiotensins. Curr Opin Nephrol Hypertens. 2001;10:321-9.

27. Suzuki Y, Ruiz-Ortega M, Gomez-Guerrero C, Tomino Y, Egido J. Angiotensin II, the immune system and renal diseases: another road for RAS? Nephrol Dial Transplant. 2003;18:1423-26.

28. Remuzzi G, Bertani T. Pathophysiology of progressive nephropathies. N Engl J Med. 1998;339:1448-56.

29. Yoshioka T, Rennke HG, Salant DJ, Deen WM, Ichikawa I. Role of abnormally high transmural pressure in the permselectivity defect of glomerular capillary wall: a study in early passive Heymann nephritis. Circ Res. 1987;61:531-8.

30. Lewis EJ, Hunsicker LG, Bain RP, Rohde RD. The effect of angiotensin-converting-enzyme inhibition on diabetic nephropathy. The Collaborative Study Group. N Engl J Med. 1993;329:1456-62.

31. The GISEN Group (Gruppo Italiano di Studi Epidemiologici in Nefrologia). Randomised placebo-controlled trial of effect of ramipril on decline in glomerular filtration rate and risk of terminal renal failure in proteinuric, non-diabetic nephropathy. Lancet. 1997;349:1857-63.
32. Maschio G, Alberti D, Janin G, Locatelli F, Mann JF, Motolese M, Ponticelli C, Ritz E, Zucchelli P. Effect of the angiotensinconverting-enzyme inhibitor benazepril on the progression of chronic renal insufficiency. The Angiotensin-Converting-Enzyme Inhibition in Progressive Renal Insufficiency Study Group. N Engl J Med. 1996;334:939-45.

33. Lewis EJ, Hunsicker LG, Clarke WR, Berl T, Pohl MA, Lewis JB, Ritz E, Atkins RC, Rohde R, Raz I, Collaborative Study Group. Renoprotective effect of the angiotensin-receptor antagonist irbesartan in patients with nephropathy due to type 2 diabetes. N Engl J Med. 2001;345:851-60.

34. Brenner BM, Cooper ME, de Zeeuw D, Keane WF, Mitch WE, Parving HH, Remuzzi G, Snapinn SM, Zhang Z, Shahinfar S, RENAAL Study Investigators. Effects of losartan on renal and cardiovascular outcomes in patients with type 2 diabetes and nephropathy. N Engl J Med. 2001;345:861-9.

35. Barnett AH, Bain SC, Bouter P, Karlberg B, Madsbad S, Jervell J, Mustonen J, Diabetics Exposed to Telmisartan and Enalapril Study Group. Angiotensin-receptor blockade versus convertingenzyme inhibition in type 2 diabetes and nephropathy. $\mathrm{N}$ Engl J Med. 2004;351:195219-61.

36. Casas JP, Chua W, Loukogeorgakis S, et al. Effect of inhibitors of the renin-angiotensin system and other antihypertensive drugs on renal outcomes: systematic review and meta-analysis. Lancet. 2005;366:2026-33.

37. Huang XR, Chen WY, Truong LD, Lan HY. Chymase is upregulated in diabetic nephropathy: implications for an alternative pathway of angiotensin II-mediated diabetic renal and vascular disease. J Am Soc Nephrol. 2003;4:1738-47.

38. Staessen J, Lijnen P, Fagard R, Verschueren LJ, Amery A. Rise in plasma concentration of aldosterone during long term angiotensin II suppression. J Endocrinol. 1981;91:457-65.

39. Fyhrquist F, Saijonmaa O. Renin-angiotensin system revisited. J Intern Med. 2008;64:224-36.

40. Kunz R, Friedrich C, Wolbers M, Mann JF. Meta-analysis: effect of monotherapy and combination therapy with inhibitors of the renin angiotensin system on proteinuria in renal disease. Ann Intern Med. 2008;148:30-48.

41. Susantitaphong P, Sewaralthahab K, Balk EM, Eiam-ong S, Madias NE, Jaber BL. Efficacy and safety of combined vs. single renin-angiotensin-aldosterone system blockade in chronic kidney disease: a meta-analysis. Am J Hypertens. 2013;26:424-41.

42. Maione A, Navaneethan SD, Graziano G, et al. Angiotensinconverting enzyme inhibitors, angiotensin receptor blockers and combined therapy in patients with micro- and macroalbuminuria and other cardiovascular risk factors: a systematic review of randomized controlled trials. Nephrol Dial Transplant. 2011; 26:2827-47.

43. Meier P, Maillard MP, Meier JR, Tremblay S, Gauthier T, Burnier M. Combining blockers of the renin-angiotensin system or increasing the dose of an angiotensin II receptor antagonist in proteinuric patients: a randomized triple-crossover study. J Hypertens. 2011;29:1228-35.

44. Nakao N, Yoshimura A, Morita H, Takada M, Kayano T, Ideura T. Combination treatment of angiotensin-II receptor blocker and angiotensin-converting-enzyme inhibitor in non-diabetic renal disease (COOPERATE): a randomised controlled trial. Lancet. 2003;361:117-24.

45. The Editors of The Lancet. Retraction-combination treatment of angiotensin-II receptor blocker and angiotensin-convertingenzyme inhibitor in non-diabetic renal disease (COOPERATE): a randomised controlled trial. Lancet. 2009;374:1226.

46. Mann JF, Schmieder RE, McQueen M, Dyal L, Schumacher H, Pogue J, Wang X, Maggioni A, Budaj A, Chaithiraphan S, Dickstein K, Keltai M, Metsärinne K, Oto A, Parkhomenko A, Piegas LS, Svendsen TL, Teo KK, Yusuf S, ONTARGET 
investigators. Renal outcomes with telmisartan, ramipril, or both, in people at high vascular risk (the ONTARGET study): a multicentre, randomised, double-blind, controlled trial. Lancet. 2008;372:547-53.

47. Staessen JA, Li Y, Richart T. Oral renin inhibitors. Lancet. 2006;368:1449-56.

48. Parving HH, Persson F, Lewis JB, Lewis EJ, Hollenberg NK, AVOID Study Investigators. Aliskiren combined with losartan in type 2 diabetes and nephropathy. $\mathrm{N}$ Engl J Med. 2008;358:2433-46.

49. Fried LF, Duckworth W, Zhang JH, O'Connor T, Brophy M, Emanuele N, Huang GD, McCullough PA, Palevsky PM, Seliger S, Warren SR, Peduzzi P, VA NEPHRON-D Investigators. Design of combination angiotensin receptor blocker and angiotensin-converting enzyme inhibitor for treatment of diabetic nephropathy (VA NEPHRON-D). Clin J Am Soc Nephrol. 2009;4:361-68.

50. Maione A, Nicolucci A, Craig JC, Tognoni G, Moschetta A, Palasciano G, Pugliese G, Procaccini DA, Gesualdo L, Pellegrini F, Strippoli GF, LIRICO study group. Protocol of the long-term impact of ras inhibition on cardiorenal outcomes (LIRICO) randomized trial. J Nephrol. 2007;20:646-55.

51. Preventing ESRD in Overt Nephropathy of Type 2 Diabetes (VALID). http://clinicaltrials.gov/ct2/show/study/NCT00494715.

52. Wang CT, Zou LX, Navar LG. Renal responses to AT1 blockade in angiotensin II-induced hypertensive rats. J Am Soc Nephrol. 1997;8:535-42.

53. Rakugi H, Wang DS, Dzau VJ, Pratt RE. Potential importance of tissue angiotensin-converting enzyme inhibition in preventing neointima formation. Circulation. 1994;90:449-55.

54. Wagner J, Gehlen F, Ciechanowicz A, Ritz E. Angiotensin II receptor type 1 gene expression in human glomerulonephritis and diabetes mellitus. J Am Soc Nephrol. 1999;10:545-51.

55. Schmieder RE, Klingbeil AU, Fleischmann EH, Veelken R, Delles C. Additional antiproteinuric effect of ultrahigh dose candesartan: a double-blind, randomized, prospective study. J Am Soc Nephrol. 2005;16:3038-45.

56. Rossing K, Schjoedt KJ, Jensen BR, Boomsma F, Parving HH. Enhanced renoprotective effects of ultrahigh doses of irbesartan in patients with type 2 diabetes and microalbuminuria. Kidney Int. 2005;68:1190-8.

57. Hollenberg NK, Parving HH, Viberti G, Remuzzi G, Ritter S, Zelenkofske S, Kandra A, Daley WL, Rocha R. Albuminuria response to very high-dose valsartan in type 2 diabetes mellitus. J Hypertens. 2007;25:1921-6.

58. Burgess E, Muirhead N, de Rene Cotret P, Chiu A, Pichette V, Tobe S, SMART (Supra Maximal Atacand Renal Trial) Investigators. Supramaximal dose of candesartan in proteinuric renal disease. J Am Soc Nephrol. 2009;20:893-900.

59. Hou FF, Xie D, Zhang X, Chen PY, Zhang WR, Liang M, Guo ZJ, Jiang JP, Renoprotection of Optimal Antiproteinuric Doses (ROAD) Study. A randomized controlled study of Benazepril and Losartan in chronic renal insufficiency. J Am Soc Nephrol. 2007;18:1889-98.

60. Bianchi S, Bigazzi R, Campese VM. Long-term effects of spironolactone on proteinuria and kidney function in patients with chronic kidney disease. Kidney Int. 2006;70:2116-23.
61. Bomback AS, Kshirsagar AV, Amamoo MA, Klemmer PJ. Change in proteinuria after adding aldosterone blockers to ACE inhibitors or angiotensin receptor blockers in CKD: a systematic review. Am J Kidney Dis. 2008;51:199-211.

62. Navaneethan SD, Nigwekar SU, Sehgal AR, Strippoli GF. Aldosterone antagonists for preventing the progression of chronic kidney disease: a systematic review and meta-analysis. Clin J Am Soc Nephrol. 2009;4:542-51.

63. Mehdi UF, Adams-Huet B, Raskin P, Vega GL, Toto RD. Addition of angiotensin receptor blockade or mineralocorticoid antagonism to maximal angiotensin-converting enzyme inhibition in diabetic nephropathy. J Am Soc Nephrol. 2009;20:2641-50.

64. Ruggenenti P, Fassi A, Ilieva AP, Bruno S, Iliev IP, Brusegan V, Rubis N, Gherardi G, Arnoldi F, Ganeva M, Ene-Iordache B, Gaspari F, Perna A, Bossi A, Trevisan R, Dodesini AR, Remuzzi G, Bergamo Nephrologic Diabetes Complications Trial (BENEDICT) Investigators. Preventing microalbuminuria in type 2 diabetes. N Engl J Med. 2004;351:1941-51.

65. Ruggenenti P, Perna A, Ganeva M, Ene-Iordache B, Remuzzi G, ENEDICT Study Group. Impact of blood pressure and angiotensin-converting enzyme inhibitor therapy on new-onset microalbuminuria in type 2 diabetes: a post-hoc analysis of the BENEDICT trial. J Am Soc Nephrol. 2006;17:3472-81.

66. Ninomiya T, Perkovic V, de Galan BE, Zoungas S, Pillai A, Jardine M, Patel A, Cass A, Neal B, Poulter N, Mogensen CE, Cooper M, Marre M, Williams B, Hamet P, Mancia G, Woodward M, Macmahon S, Chalmers J, ADVANCE Collaborative Group. Lowering blood pressure reduces renal events in type 2 diabetes. J Am Soc Nephrol. 2009;20:883-92.

67. Bilous R, Chaturvedi N, Sjølie AK, Fuller J, Klein R, Orchard T, Porta M, Parving HH. Effect of candesartan on microalbuminuria and albumin excretion rate in diabetes: three randomized trials. Ann Intern Med. 2009;151:11-20.

68. Mauer M, Zinman B, Gardiner R, Suissa S, Sinaiko A, Strand T, Drummond K, Donnelly S, Goodyer P, Gubler MC, Klein R. Renal and retinal effects of enalapril and losartan in type 1 diabetes. N Engl J Med. 2009;361:40-51.

69. Haller H, Ito S, Izzo JL Jr, Januszewicz A, Katayama S, Menne J, Mimran A, Rabelink TJ, Ritz E, Ruilope LM, Rump LC, Viberti G, ROADMAP Trial Investigators. Olmesartan for the delay or prevention of microalbuminuria in type 2 diabetes. N Engl J Med. 2011;364:907-17.

70. Sarafidis PA, Khosla N, Bakris GL. Antihypertensive therapy in the presence of proteinuria. Am J Kidney Dis. 2007;49:12-26.

71. Leoncini G, Viazzi F, Pontremoli R. Chronic kidney disease and albuminuria in arterial hypertension. Curr Hypertens Rep. 2010;12:335-41.

72. Bakris GL, Sarafidis PA, Weir MR, Dahlöf B, Pitt B, Jamerson K, Velazquez EJ, Staikos-Byrne L, Kelly RY, Shi V, Chiang YT, Weber MA, ACCOMPLISH Trial investigators. Renal outcomes with different fixed-dose combination therapies in patients with hypertension at high risk for cardiovascular events (ACCOMPLISH): a prespecified secondary analysis of a randomised controlled trial. Lancet. 2010;375:1173-81. 